The (Community Care) document also suggests that the assessment beds for the elderly are to be provided from within the acute general psychiatric beds, (The Hospital Advisory Services' Rising Tide makes it quite clear that assessment beds for the elderly are in addition to the acute general psychiatric beds). In Dudley, using the bed norm of one bed per 1000 population over 65 years, this would mean that we should set aside up to 47 beds out of our total of 72 beds. It is difficult to see how we could provide a service for our 319,000 catchment area population with the remaining 25 beds!

The Old Age section of the Royal College of Psychiatrists is making strong representation to the Department of Health about the situation. I feel that general psychiatrists who are involved in the planning process should be aware of what is happening in our District.

Barnsley Hall Hospital

MARgaret BEEDIE

Bromsgrove

\section{When Approved Social Workers refuse to make applications for admission}

\section{DeAr SIRS}

Lives there the Psychiatrist with practice so pacific who yet hath not fought verbal wars so terrific with approved social worker whose ken's so myopic he seeth not the madness for the insanity so horrific. .

It would surprise me to hear of a doctor, regularly involved in the admission of patients under the provisions of various Sections of the Mental Health Act, ${ }^{1}$ who has not, on at least one occasion, had the experience of an Approved Social Worker who, regardless of medical recommendations, refuses to make the application for admission.

Most doctors find this annoying and frustrating, to put it mildly, especially when their best judgement tells them that the patient genuinely needs to be in hospital, and that there is a risk of the patient harming himself or others.

There are various reasons why the refusal to make an application causes doctors so much difficulty, First, it is perceived as a challenge to medical authority by people who have no training in the diagnosis and treatment of mental disorders. Whatever reason an Approved Social Worker may present for refusing to make an application, it should not be that he or she disagrees with the diagnosis made by the doctors. Secondly, it appears that the Approved Social
Worker bears no responsibility for the consequences of his/ her decision not to make an application for admission, apart from informing the doctors (verbally) and the relatives (in writing) of the reasons for the decision. This is stated very clearly in paragraph 1.17.8 of the Draft Code of Practice ${ }^{2}$ (with reference to just such situations): 'In these circumstances, there is no further duty on the Approved Social Worker, and he is not obliged to provide the relevant Forms..."

What makes it all so unsatisfactory is that an Approved Social Worker can come into the situation, prevent an admission recommended by the doctors, and walk away, without any responsibility for the consequences of the decision, and without the obligation to provide an alternative to the admission recommended. In the case of patients already in hospital, the refusal to make an application often leaves the doctors and nurses with a very disturbed patient on whom treatment can only be enforced under Common Law until the situation with respect to detention under the Act is rectified.

To be completely fair, there are many instances where doctors feel that a patient should be detained under the Act, the Approved Social Worker has thought otherwise, and the patient has gone on to be treated successfully informally. But in my experience, it has been more the rule than the exception that the Approved Social Worker who refuses to make an application has had to be recalled later to do so; and has then gone on to sign the forms.

I believe that the following recommendations will receive the approval of all those doctors who are regularly involved in the compulsory admission and treatment of patients:

(a) Part of paragraph 1.16.5 of the Draft Code of Practice states that "the ASW need not question the doctor's indication that mental disorder is present...". This should be recast to state that the ASW should not question the doctor's diagnosis, as the ASW does not have the experience or the legal right to make medical diagnoses. (b) It is not right that the ASW should have the authority to block an admission, but have no responsibility for the outcome of his action. Paragraphs 1.17.7-9 of the Draft Code of Practice should therefore be rephrased to specify that the ASW who refuses to make an application is obliged to provide an alternative for the patient, and is to be held to account if the patient or other people should come to any harm as a result of the refusal to make the application for admission.

An Approved Social Worker was once heard to say: "The doctors go in and say their bit; then we move in and make the final decision..."

Surely, such power must go with at least some responsibility?

\section{Claybury Hospital}

I.O. AZUONYE

Woodford Green, Essex

REFERENCES

${ }^{1}$ Mental Health Act 1983. London: HMSO

${ }^{2}$ Mental Health Act 1983: Section 118-Draft Code of Practice. London: DHSS. 